\begin{tabular}{|c|c|c|}
\hline ב & $\begin{array}{c}\text { International Journal of Current Research } \\
\text { and Academic Review }\end{array}$ & \\
\hline $\begin{array}{l}\text { EXCELLENT } \\
\text { PUBLISHERS } \\
\end{array}$ & $\begin{array}{l}\text { ISSN: 2347-3215 (Online) Volume } 6 \text { Number } 7 \text { (July-2018) } \\
\text { Journal homepage: http://www.ijcrar.com }\end{array}$ & \\
\hline
\end{tabular}

doi: https://doi.org/10.20546/ijcrar.2018.607.009

\title{
Review on Rural Livelihood Diversification Strategies in Ethiopia
}

\author{
Agidew Abebe* \\ Department of Rural Development and Agricultural Extension, College of Agricultural Sciences, Arba Minch \\ University, Arba Minch, Ethiopia \\ *Corresponding author
}

\begin{abstract}
This review was focused of rural livelihood diversification strategies in Ethiopia. The similarities and variation among different findings in different area were reviewed. Some of variation reviewed in the methodology part was some authors have used multinomial logistic model and others have used OLS (ordinary least square) model. The model findings were also varied i.e. in some areas significantly positive effect variables also showed that significantly negative effect in the other areas.
\end{abstract}

\section{Article Info}

Accepted: 04 June 2018

Available Online: 10 July 2018

\begin{tabular}{ll} 
Keywords \\
\hline OLS; Logistic; Livelihood; \\
Diversification
\end{tabular}

\section{Introduction}

Agriculture is an important sector for majority of the rural populations' livelihood in developing countries. It has been the predominant activity for most rural households in Sub-Saharan Africa (SSA) which offers a strong option for spurring growth, overcoming poverty, and enhancing food security (World Bank, 2008).

The Ethiopian economy is largely dependent on the agricultural sector. Its contribution for GDP is 41 percent, export is 90 percent, employment is 85 percent and food security is high.

The small-scale farming dominates the agricultural sector and accounts for 95 percent of the total area under crop and more than 90 percent of crop output.

The livelihoods of $84 \%$ of the citizens depend on various agricultural productions (Fikremarkos, 2012). However, the largest share of the small-scale production of crops goes to household consumption (66\%), while $16 \%$ goes for seed and $14 \%$ for sale. The remaining share goes to wages, animal feed, etc. (CSA, 2010).

In addition, farming as a primary source of income has become failed to guarantee sufficient livelihood for most farming households in Sub-Sahara African countries (Babatunde, 2013).

Furthermore, the agricultural activities in rural Ethiopia is also dominated by smallholders, the majority cultivating less than 0.5 ha and producing mostly basic staples for the subsistence of their households (Arega et al., 2013).

Thus, the expectation that achieving the goal of reducing poverty only through increasing agricultural productivity and redressing the issues of access to key agricultural resources without non/off-farm livelihood diversification could not be successful in the sub-Sahara African countries (Emanuel, 2011). 


\section{Empirical findings}

\section{Major livelihood diversification strategies}

Households in the study area engaged in few income generating activities, can be both farm/pastoral and nonfarm/pastoral activities. The sampled households reported that they had engaged in one or more income generating activities, among livestock production system, crop production, petty trade, remittance, handcrafts, daily laborer, and selling firewood and charcoal are important. Out of the total households surveyed only $19.21 \%$ were reported as being participated in off/non-farm/nonpastoral sectors. The survey result indicates that in the study site fire wood and charcoal selling is the dominant off-farm sector that is practiced by about $9.16 \%$ of households. It is followed by petty trade (include shop, livestock and crop trading) which accounts for $5.85 \%$. This implies fire wood and charcoal selling are one of the most common non-pastoral/ non-farm income generating activities in the study area. This finding may indicate the limited options available for pastoralists to diversify their economy.

It is widely recognized that fuel wood and charcoal selling is an occupation of the poor pastoralists across East Africa that arises out of desperation. This may lead to conflict within communities between those who make charcoal and those in charge of natural resource management (Adugna, 2012). This was realized by FGD discussions, as the participants were filled with vehement accusation of charcoal makers for cutting down trees. So that, the negative environmental impact of charcoal making is clear to pastoralists themselves as well as government officials. But, the magnitude of poverty and availability of limited options pushes pastoral households to engage in such low return activities to address this problem.

During the course of this study it was found that livestock have been the main assets of pastoralists in the study area with an average livestock holding per household of 10.28in TLU (Tropical Livestock Units = $250 \mathrm{~kg}$ non-lactating animal.

Livestock were also used as sources of food and income generating activities (mainly milk from cattle, goats and camels, and occasionally meat), as well as for social functions and transportation and to supply draught power. $90.59 \%$ of respondents derived income from livestock, selling small ruminants and dairy products. Camels and cattle have been used in society as a 'savings account', while small ruminants constitute liquid assets, often being sold during emergencies and at the time of crop failure.

\section{Determinants of livelihood diversification strategies}

According to Baharu Gebreyesus (2016), Age of the household head negatively affected the level of livelihood diversification at 5 percent significance level. A one percent increase in age of the household head caused decrease in the level of diversification by 0.006347 percent. The possible reason may be it is related to the natural factors in that as age of the farm household increases, the farmer will be getting older and older and may not be capable of diversifying as many livelihood activities as possible and may concentrate only to the on-farm agricultural activities for the purpose of maximizing subsistence consumption needs.

The researchers argued that aged household head may have a larger family size and expected to have extra and unemployed labor, which will lead them to allocate some proportion of their labor outside the agriculture sector.

As expected, the educational level was found to affect positively the livelihood diversification of the households at 5\% significance level. The result indicated that improvement in the education level increase the possibility of engagement in non/off-farm activities. This implies that the highly educated persons diversify their livelihood options through opting for salaried jobs, selfemployment activities, etc., whereas low educated and illiterate persons engage themselves in wage earning. On the other hand, the studies conducted by Kassiye (2013) in Ethiopia found opposite results in that educational level of the farm household has a negative impact for livelihood diversification.

Contrary to the expectation, livestock holding affected the level of livelihood diversification significantly and negatively at 5\% level of significance. As the livestock number increases by one unit, the probability of engagement in livelihood diversification decreases by 0.10 percent.

The possible reason could be households who obtained the required amount of cash from livestock may not need to involve in non/off-farm activities for additional income whereas farmers with lower livestock holding may be obliged to diversify livelihoods into off/non-farm activities to fulfill household assets. This finding is similar with the finding of Yenesew et al., (2015). 
However, Amare and Belayneh (2012) found that livestock holding significantly and positively influence livelihood diversification. Households with more livestock holding do have the capacity to participate in lucrative non/off-farm employment activities than those households with no or small size livestock holding.

As hypothesized, the numbers of non/off-farm activities have a positive and significant influence on the livelihood diversification at less than $1 \%$ level of significance. The positive coefficient indicates that the level of livelihood diversification of households who have been engaged in large number of non/off-farm activities increased by 0.32 percent. This means households involved in various non/off-farm activities have livelihood diversification opportunities.

The walking distance to the nearest market yielded positive and significant influence on the level of livelihood diversification at 5 percent level of significance. As the market distance increases by $1 \mathrm{~km}$ the level of livelihood diversification of the household increases by 0.052 percent. The possible reason for positive and significant relationship between market distance and non/off-farm diversification could be that residing nearer to the market enables farm households to engage in non/off-farm activities particularly trading and service provision.

This result agrees with Amare and Belayneh (2013) finding that market distance positively influenced livelihood diversification in Ethiopia. Contrary to this result, Yenesew et al., (2015) found negative correlation between market distance and livelihood diversification. Credit facilities (CREDCOST): As expected, access to formal credit was found to have a positive effect on the level of livelihood diversification at 1 percent level of significance. The positive coefficient indicates that as farm households access to credit facilities increases, the possibility of farming rural households' engagement into non/off-farm livelihood diversification strategies increases by $0.00001171 \%$. Since resource-base is very poor for most of the rural households, providing credit to them will improve their livelihood.

The farm size is significantly and negatively related to livelihood diversification at less than $1 \%$ level of significance. The negative coefficients indicated that the households with large farm size are less diversified and rely more on agriculture livelihood strategy. The livelihood diversification of large farm households into non/off-farm activities other than agriculture decreases by $0.28 \%$ as the farm size increases by one hectare. From this result it is evident that small holder farm households diversify more than large farm households. The possible reason can be a smaller amount of cultivated land is not enough to the households to make a sufficient living from farm production alone, causing them to work for supplementary non/off farm income generating activities. This finding is in agreement with that of Yenesew et al., (2015).

On the contrary to this result, Kebede et al., (2014) found that the total cultivated land size has positive and significant influence on non/off-farm production perhaps households with better holding opted for additional income in casual labor works to smoothen their farm operations. Location dummy (KACHADIST): The location of households in Kachabira district positively affected the level of livelihood diversification at 5\% significance level. The households in Kachabira were more diversified than that of the omitted households in Kadidagamela district. A household in Kachabira district increased his/her level of livelihood diversification by 0.07 percent. The possible justification may be the resource endowments differences between the districts that create variations in diversification activities among districts.

According to Birhanu Negeri and Getachew Demissie 2016, the results of the estimated marginal effects are discussed below in terms of the significance and signs on the parameters. The positive estimated coefficients of continuous variable indicates that the probability of the household higher and moderate livelihood diversifications level categories' relative to less diversification status would increase as these explanatory variables allowed to increase by a unitary value. The implication is that the probability of the pastoral and agro-pastoral households to be on these outcomes is greater than the probability of being in less diversified livelihood level (the base category). The negative and significant parameter indicates the probability of falling back to the base category that is less diversified livelihood levels.

The Educational Level (EDULEVEL) of household head was found to have positive correlation with highly diversified livelihood and moderately diversified strategy, so that it was found to be one of the important determinants of livelihood diversification. Elementary, Junior and Secondary Education of household head found to be significant at $\mathrm{p}<0.01$. This finding indicates that those households with high educational level are 
more likely diversify livelihood strategies into moderately and highly diversified level than those do not. Therefore, the finding confirms that an increase in education level of head will increase the likelihood of being in highly and moderately diversified compared to the probability of being in less diversified strategy. This is due to most probably educated person gain better skill, experience, knowledge, literate individuals are very ambitious to get information and determine the capacity of finding jobs and these help them to engage in diversified livelihood strategies. This finding is similar with that of Ng'ang'a, et al., (2011) assumed education as an essential in increasing off/non-farm earnings and time allocation of rural families and to diversify the rural economy away from agriculture. Therefore, investing in education and increasing access to education will help the pastoralist households in getting alternative income as it increases the probability of engagement in rural non-farm activities and livelihood diversification.

Age of Household Head (AGEHEAD): From the multinomial estimation for diversification levels it was found that the probability of having highly diversified livelihood category is affected positively and significantly by age of the respondent. The model result indicated that the age of household head influenced positively and significantly the household's livelihood diversification strategy at less than $1 \%$ and $10 \%$ probability level. In other words, multiplicity of activities increases with advancing age. This is because, experience increases with age, and consequently, experienced persons have more prospects of diversifying livelihood strategies. From the model result, other variables being kept constant, the probability of households' being either highly diversified or moderately diversified will be increased by $0.16 \%$ with aunit change in age. This is in lined with Dilruba and Roy (2012) found that household head's age is the main driving force towards livelihood diversification. Therefore, the marginal effect of the respondent's age is $0.0016(0.16 \%)$ showing that those aged households prefer to diversify their livelihood options relative to those who are younger in the study area.

Sex of Head (SEXHEAD): It was found that the probability of having highly diversified livelihood category is affected positively and significantly by sex of the respondent. Being male headed household was found positively and significantly to affect the likelihood of highly diversified livelihood categories. The marginal effect of being male indicates that, if the household is male headed, the likelihood of having highly diversified livelihood options by $1.6 \%$ relative to base category (less diversified livelihood categories').

Livestock Holding in TLU (LIVESTOK) is found to have a significant (at $\mathrm{P}<0.01$ and $\mathrm{P}<0.1$ ) negative correlation reducing the probability of being in either moderately or highly diversified household, respectively. This implies that the likelihood of a household's diversification decreases with the size of livestock holding. In other words, this result suggests that a household having larger size of livestock are less likely to diversify the livelihood strategies into non-farm/ nonpastoral and/or off-farm activities compared to those who own small number of TLUs. Therefore, the negative association between livelihood diversification and number of TLU indicates that herd size creates better opportunity to earn more income from livestock production. According to this study, keeping other variables constant, then likelihood of diversifying into moderate or highly diversified level decrease by $3.43 \%$ and $0.67 \%$ respectively, for those households with more TLU. Study by Adugna (2012) supports this idea.

Distance to Market (DISTMARK): Is found to have a significant $(\mathrm{P}<0.1$ and $\mathrm{P}<0.01)$ negative correlation with reducing the probability of being both highly diversified and moderately diversified household, respectively. This negative relationship tells us that the larger the distance the lesser the tendency of households to diversify and vice versa. The possible justification could be households who are closer to the market centers do not have much cost to access market incentive for diversification of livelihoods. From the model result, the marginal effect reveals the likelihood of a household diversifying into moderate and high level of diversification increase by $0.34 \%$ and $1.31 \%$, respectively, as a household is near to market center by one kilometer. In other words, distance from nearest local market center decreases the probability of finding the households in highly diversified categories' by 1.31 $\%$ (highly diversified) and by $0.34 \%$ (moderately diversified) relative to those in less diversified categories'. This finding is in agreement with that of Ibrahim et al., (2009) argues that distance from market center influences decision to build highly diversified livelihood options.

Access to Credit Service (CRDTACSS) was found to have a positive effect on the level of livelihood diversification. The co-efficient was statistically significant (at $\mathrm{P}<0.01$ and $\mathrm{P}<0.05$ ) level of probability. Since resource-base is very poor for most of the rural 
households, providing credit to households will improve their livelihood. This finding is in line with Birhanu (2014). On the other hand, there are several challenges to successful livelihood diversification. Identification of such challenges in pastoral area is crucial for future policy formulation. Cognizant to this fact, this study tried to identify some of the socio-economic, environmental, institutional and policy constraints/challenges to livelihood diversification. These include: shortage of land and decline in rangeland productivity, lack of credit facilities, market and marketing facility, road and transport problem, crop and animal disease as well as agro-climatic condition.

\section{References}

Adugna, E. (2008). Livelihood strategies and food security in Wolayta, Southern Ethiopia: The case of Boloso Sore district. A Thesis submitted to the School of Graduate Studies, Haramaya University.

Adugna, E., Determinants of livelihood diversification in pastoral societies of southern Ethiopia, (2012), Available Online at http://www.onlineresearchjournals.org/ JABR.

Amare, D., and Belaineh, L. (2013). Determinants of income diversification among rural households: The case of smallholder farmers in Fedis district, Eastern Hararghe zone, Ethiopia. J. Develop. Agric. Econ., 5(3), Journal of Poverty, Investment and Development www.iiste.org ISSN 2422-846X An International Peer-reviewed Journal Vol.23, 2016 120-128. Available online at http://www.academicjournals.org/

Arega, B., Woldeamlak, B., and Melanie, N. (2013). Rural households' livelihood assets, strategies and outcomes in drought-prone areas of the Amhara Region, Ethiopia: Case Study in Lay Gaint District. Afr. J. Agric. Res., 8(46), 5716-5727. Available online at http://www.academic journals.org/AJAR.

Babatunde R.O (2013). On-Farm and Off-farm Works: Complement or Substitute? Evidence from Rural Nigeria. Contributed paper for the 4th International Conference of the African Association of Agricultural Economists, September 22-25, 2013, Hammamet, Tunisia. URL: http://ageconsearch.umn.edu.

Baharu Gebreyesus (2016). Determinants of Livelihood Diversification: The Case of Kembata Tambaro Zone, Southern Ethiopia Department of Sociology, Mahatma Gandhi University, Meghalaya, India.

Birhanu Negeri and Getachew Demissie (2016). Livelihood Diversification: Strategies, Determinants and Challenges for Pastoral and Agro-Pastoral Communities of Bale Zone, Ethiopia

Birhanu, N., The role of irrigation development in enhancing household food security: A study of two small scale irrigation schemes in Bale Zone, Ethiopia, PhD Thesis, (2013), Osmania University, India.

Central Statistical Agency of Ethiopia (2003-2009/10). Report on Area and Production of Major Crops. Agriculture Sample Survey 2003-2009/10. Volume I: (Private Peasant holdings, Meher Season).

Emanuel E (2011). Rural Livelihood Diversification and Agricultural household welfare in Ghana. J. Develop. Agric. Econ., 3(7), 325-334. Available online at http://www.academicjournals.org/JDAE.

Eneyew Adugna (2012). Determinants of Livelihood Diversification in pastoral societies of Southern Ethiopia.Journal of Agriculture and Biodiversity Research. 1, (3), 43-52; retrieved on October 2015.

Fikremarkos, M. B. (2012). Ethiopia's World Trade Organization accession and maintaining policy space in intellectual property policy in the agreement on trade-related aspects of Intellectual Property Rights Era: A preliminary look at the Ethiopian patent regime in the light of the agreement on trade-related aspects of intellectual property rights obligations and flexibilities. The J. of World Intellectual Property, 15(3), 171-198.

Ibrahim, H., S.A. Rahman, E.E. Envulus and S.O. Oyewole, Income and crop diversification among farming households in a rural area of north central Nigeria, Agro-Sci. J. Trop. Agric. Food Environ. Extension, 8(2) (2009), 8489.

Kassie G. (2013). Livelihood diversification and Sustainable land management: The case of North East Ethiopia. Retrieved from www.apu.ac.jp/media/library/thesis/_spring.html

Kebede, M., Haileselassie, A.G., Haile, M., and Luchia T. (2014). Livelihood diversification strategies among men and women rural households: Evidence from two watersheds of Northern Ethiopia. J. Agric. Econ. Develop, 3(2), 017-025. Available online at http://academic research journals.org/journal /jaed.

Khatun, D., and B.C. Roy, Rural livelihood diversification in West Bengal: Determinants and constraints, Agricultural Economics Research Review, 25(1) (January-June) (2012), 115-124.

Ng'ang'a, S.K., V. Jeannette, A. Notenbaert, S. Moyo and M. Herrero, Household livelihood strategies and livestock benefits dependence in Gaza province of Mozambique, Afri. J. Agric. Res., 6(3) (2011), 560572. 
World Bank (2008). World Development Report 2008: Agriculture for Development Washington, DC.

Yenesew, S. Y., Eric, N. O., and Fekadu, B. (2015). Determinants of livelihood diversification strategies:
The case of smallholder rural farm households in Debre Elias Woreda, East Gojjam Zone, Ethiopia. African Journal of Agricultural Research, 10, 19982013. doi: 10.5897/AJAR2014.9192.

\section{How to cite this article:}

Agidew Abebe. 2018. Review on Rural Livelihood Diversification Strategies in Ethiopia. Int.J.Curr.Res.Aca.Rev. 6(7), 81-86. doi: https://doi.org/10.20546/ijcrar.2018.607.009 